\title{
Analysis on the Limitations and Development Perspectives within Judicial Accounting and Fiscal Expertise
}

\author{
Riana Iren RADU ${ }^{\star}$, Oana Daniela LUPOAIE ${ }^{\star \star}$, Andrei Mirel FLOREA
}

\begin{tabular}{l}
\hline \multicolumn{1}{c}{ A R T I C L E I N F O } \\
\hline Article history: \\
Accepted June 2019 \\
Available online August 2019 \\
\hline JEL Classification \\
M48, M41 \\
Keywords: \\
Fiscal expertise, Accounting \\
expertise, Competencies, \\
Professional bodies
\end{tabular}

1. Introduction

The organizations are facing a series of challenges in the actual economic scenario. They are constantly facing the pressure of doubtful markets, the increase of production costs and the constant need of labor force and technology development. In the context of constant changes in the business environment, the need to adapt to it represents a prerequisite for the sustainable development of the organizations. The need to keep the pace with these constant changes generates a high exposure to the fraud of organizations.

Romania, found in full transition towards a market economy, has been always searching for its own path in the process of accounting implementation and regulation (Dobre, 2003). According to Borlea et al (2008), the real consolidation of the Romanian accounting reform started along with its harmonization with the European Directives and International Accounting Standards (Order of the Ministry of Public Finances no. 403/1999) for large and very large entities and respectively, its harmonization with the European Directives (Order of the Ministry of Public Finances no. 306/2002) only for small entities.

The important evolution of the Romanian business environment, the significant increase of the complexity of tax regulations applicable in the context of the adhesion of Romania to the European Union, as well as the increase of the number of foreign investors in Romania have imposed the regulating of the tax accounting expertise activity and the creation of a legal framework necessary for providing independently services at the highest professional level.

Considering the diversification of the business environment, the accounting - finance services become more and more important, and the accounting and tax professionals are forced to adapt and to constantly develop in order to help the economic entities to continue to compete in the conditions of globalization.

At present, the fraud is more sophisticated and more devastating than ever. Over the last few years, the complicated nature of modern fraud has led to the increase of the role of judicial experts. Often trained both in accounting, taxability and in criminal investigation, the judicial experts play a huge part in the criminal justice and in civil litigations. Many financial disputes require special attention which no knowledgeable lawyer can offer. The accounting professionals and tax advisors can intervene by puzzling out complicated financial problems and sending them in such a way so that even the lawyers and clients can understand.

The fraud comes in many forms, from theft of small value up to corruption spread within global businesses. The criminal files involving financial offences can be very large and complicated, with much 
evidence to investigate. Due to the above, many lawyers require assistance from an expert accountant and/or tax advisor.

Their role proves to be valuable in the judicial expertise, by questions which must be raised in any fraud assessment, by the identification of red flags for the early detection of frauds, by their knowledge on accounting information systems and on different audit techniques and software competencies. They prove their analytic, investigation, organization and communication abilities so that to be able to explain in the end in the Courts of Law the methodology and techniques used in order to reach their conclusions (Ionescu, 2011).

The tax consultancy activity is regulated by Law no. 200/2004. Accordingly, the distinction between accounting expertise and fiscal expertise is made within the judicial expertise. The fiscal expertise can be achieved only by a tax advisor, member of The Chamber of Tax Advisors (CCF), and the accounting expertise by a member of the Body of Expert and Licensed Accountants of Romania (CECCAR).

The objectives of the present paper are represented by the analysis of the legislative regulating framework of the two professions, as well as by an empirical analysis through a case study. The latter was performed by the centralization of the affiliation of the judicial accounting and tax experts published by the Ministry of Justice under other professional organizations. In the author's opinion, the starting point is represented by the accounting documents in most cases, in order to analyze a tax problem. At the same time, the accounting professional performs all accounting documents in accordance with the tax provisions. In this context, we consider that two conditions must be fulfilled by the judicial accounting and tax experts, namely: competency and affiliation to both professional organizations (CECCAR and CCF).

\section{Research methodology}

Regarding the methods of research, the most frequently used within the paper is the comparative method, and the arguments justifying the use of this method is that it has allowed us to identify the similarities, but also the differences existing between the bodies that govern the activity of the professional and fiscal professionals.

Also, the method of analyzing the legal framework for regulating the two professions in conjunction with the comparative studies as well as the interpretations of the specialists from the national and international literature for providing a true image of the issues addressed, are also important.

The researchers' approach is an impartial one, capable of responding punctually to the following questions:

Q1: Who performs an accounting - fiscal expertise?

Q2: Within an accounting expertise, the documents taken over from accounting are issued according to the provisions of the Tax Code. Has the judicial expert accountant the competence to establish it?

Q3: In a fiscal expertise, the pieces of evidence represent accounting documents. Has the tax advisor the competence to analyze them?

The answers to these questions have a significant connection to the accuracy and quality of the accounting and fiscal expertise reports, according to the authors' opinion.

\section{Delimitations between tax - accounting professions}

In Romania, the body of the accounting profession is the Body of Expert and Licensed Accountants of Romania (C.E.C.C.A.R.). CECCAR is a member of many international specialized organizations, which promote the accounting profession, such as: International Federation of Accountants (IFAC) or the Federation of European Expert Accountants (La Federation des Experts Comptables Europeens-FEE). The Register of Expert Accountants within CECCAR comprises all expert accountants from Romania. Both the initial training and the continuous training of the accounting professionals must be done in accordance with the requirements of the accounting profession, which are regulated by the International Federation of Accountants-IFAC).

On the other hand, another profession acknowledged in the area is that of tax advisor, profession regulated by the Chamber of Financial Advisors. The Chamber of Tax Advisors from Romania is a member with full rights within the European Tax Confederation and has the responsibility to maintain a high level of the professional quality, according to the provisions of Government Ordinance no. 71/ 2001 on the organization of the tax advisory activity, approved by Law no. 198/2002 with subsequent changes and additions. In over 20 Member States of the European Union, there are professional bodies similar to the Chamber of Financial Advisors, which at the same time are part of the European Tax Confederation.

The conditions for affiliation to the two bodies are presented in Table no. 1 below. 
Table no.1 Conditions in order to become member of the two bodies

\section{CECCAR}

Economical university studies, with a diploma acknowledged by the Ministry of National Education - Bachelor level (3 years);

No requirements regarding professional experience are mentioned; after passing the admission examination, he/she must perform a 3-years internship and sit and pass the fitness for employment examination in order to access the expert accountant profession;

$\mathrm{He}$ /she must not have a criminal record for committing offenses punishable by fiscal, financial and accounting laws and other offenses in connection to exercising the provided activities

He/she must have full capacity of exercise; $\mathrm{He} / \mathrm{she}$ must be fit from medical point of view to exercise the profession;

Passing an admission examination comprising 7 disciplines (accounting, taxation, law, economic and financial evaluation of enterprises, audit, accounting expertise and accounting profession doctrine and deontology), written tests, at which the candidates must obtain a minimum grade of 6 for each discipline and at minimum an average grade of 7 for al disciplines.

Source: Processed by the author based on the information available on the sites: ccfiscali.ro and ceccar.ro
Economical university studies, with a diploma acknowledged by the Ministry of National Education - Bachelor level (3 years);

He/she must have a professional experience of minimum 2 years. After passing the examination for awarding the capacity as assistant tax advisor, a 3years internship is performed. After the finalization of the internship, the assistant tax advisor can enlist to the examination for awarding the tax advisor capacity within 2 years after finishing the internship. $\mathrm{He} / \mathrm{she}$ must not have a criminal record for committing offenses punishable by fiscal, financial and accounting, customs laws, offences on financial discipline and other offenses in connection to exercising the provided activities

$\mathrm{He} / \mathrm{she}$ must have full capacity of exercise;

$\mathrm{He} / \mathrm{she}$ must be fit from medical point of view to exercise the profession;

Passing an admission examination comprising 7 disciplines (civil and commercial law, public finances, taxability and accounting), written tests, at which the candidates must obtain a minimum grade of 6 for each discipline and at minimum an average grade of 7 for all disciplines.

It is noted that the access and support conditions are similar in a broad sense. Other disciplines are also included within the fitness for employment test that marks the end of the accounting expert's internship, such as: doctrine and deontology of the accounting profession, evaluation, economic and financial analysis of enterprises, audit and accounting expertise.

Practically, future expert accountants are required to have knowledge on evaluation and audit concepts, although these are activities they will never be able to practice without acquiring a subsequent qualification. An expert accountant, the highest qualification in the economic field, is not entitled to carry out an audit, evaluation or tax advisory activities, although he/she had passed exams in this respect, even though it represents his/her object of activity in the rest of the world.

A collaboration protocol exists between CECCAR and CCF, according to which for the expert accountants members of the two professional bodies, 10 hours of professional training in the Taxation discipline can be acknowledged within the professional development programs, upon request.

However, a tensional situation has existed for a very long time between the expert accountants and tax advisors. The main reason is the dissociation of tax advisory activities from those related to accounting. Government Emergency Ordinance no. 75/1999 and Government Ordinance no. 71/2001 have regulated this profession and have been highly contested since promulgation.

The accounting experts have claimed for a very long time the fact that the normative acts, Government Emergency Ordinance no. 75/1999 and Government Ordinance no. 71/2001 contained unconstitutional provisions for this profession, which was divided abusively and without any legal grounds or of other nature in two segments: financial audit and tax advisory.

Article 6, letter e) from Government Ordinance no. 65/1994, according to which the expert accountants could perform also works with fiscal character, was expressly abrogated by Article 26 from Government Ordinance no. 71/ 2001, subsequent normative act regulating the profession of tax advisor as liberal profession, distinct from the others, with a clear and well-shaped status.

In the former provisions, it was established that the tax advisors and the tax advisory companies can also perform besides the tax advisory activity, complying with the conditions provided by the normative acts in the area, activities of:

- accounting expertise;

- financial audit;

- training and improvement in tax area. 
By the collocation "complying with the conditions provided by the normative acts in the area", it was imposed to the tax advisors to be also expert accountants or financial auditors in order to be able to develop activities specific to these professions.

By the Order of the Ministry of Justice no. 199/2010, Annex 1- Nomenclature of the specializations of the judicial technical expertise, at point 23 , the following specializations in accounting are provided:

- Accounting - companies and other economic entities

- Accounting - credit institutions and non-banking financial institutions

- Accounting - insurance companies and other and insurance area

- Accounting - financial investment companies and other entities of securities

- Public institutions

- Non-profit organizations, including owners associations

- Accounting - salary rights, pensions, independent activities and other activities on natural persons

- Accounting - community funds management

- Accounting - taxability

The expert designation involves the fact that the person performing an expertise must have acknowledged also the capacity as expert. CECCAR acknowledges the capacity as auditor, and CCF acknowledges the capacity as tax advisor.

The main activities which can be developed by tax advisors and expert accountants have been centralized in Table no. 2.

Table no.2: The main activities which can be developed by expert accountants and tax advisors TAX ADVISOR EXPERT ACCOUNTANT

a) granting professional assistance and services in tax a) keeping or monitoring the accounting and area;

b) providing services and specialty assistance for issuing tax statements;

c) certification of tax statements, according to law provisions;

d) assistance and services on tax procedure issues;

e) assistance in the preparation of documentation for the enforcement of appeals against debt securities and other tax administrative acts;

f) assistance and representation before tax authorities, including the provision of specialized assistance during the tax inspection;

g) carrying out judicial fiscal expertise at the request of the Court or criminal investigation bodies. In this case, Art. 42 of the Law no. 134/2010 on the Civil Procedure Code, republished, as amended, shall be applied accordingly. Judicial tax audits are carried out only by the active tax advisors registered in the records of the Ministry of Justice Department of Auxiliary Legal Professions;

h) performance of extra-judicial fiscal expertise, at the request of the tax bodies or of any other interested persons or entities;

i) assistance on the receivables of consolidated general budget, complying with the legal provisions in force;

j) tax assistance in the cases in front of a jurisdictional authority. issuance of financial statements:

b) performance of economical - financial analysis

c) performance of financial - accounting audit (financial diagnose, internal audit, statutory audit and certification of Balance Sheet, with compliance to specific regulation)

d) performance of assessments according to international standards of assessment according to legal provisions

e) performance of accounting expertise decided by legal bodies or requested by legal or natural persons in the conditions provided by law

f) performance of works with financial accounting character

g) performance of works with fiscal character (studies and consultations on tax problems, participation to the issuance and submission of tax statements, assistance in VAT and tax problems, real estate taxability, endorsement of yearly tax statements of the economic operators)

h) performance of administrative and informational organization works

i) fulfillment of responsibilities provided in the auditor's mandate, according to legal provisions;

j) fulfilment of responsibilities provided by law in the procedures of judicial reorganization and bankruptcy;

k) granting specialized assistance necessary for the establishment and reorganization of trade companies;

l) performance of natural and legal persons of 
any professional service which supposes accounting knowledge;

$\mathrm{m})$ other activities and services for enterprises comprised in NACE classes: 6209, 6420, 6619, $6920,7022,7320,8299,7490,6831,6621$, as well as other established by The Permanent Bureau of Superior Council.

Source: Ordinance no. 71/2001 and Ordinance no. 65/1994

The Tax Procedure Code provides for the probative value of the supporting documents and accounting records. The fiscal record is entwined with the accounting record and as a symbiont, the fiscal activity cannot be separated from the accounting one, the lack of accounting liability actually invalidating the tax base.

Customers and suppliers, receivables and liabilities' accounting is kept according to categories, as well as according to each and every natural or legal person. An expert accountant does not only analyze a tax receivable, but also reviews the way it is presented in the accounting, if the relations between the accounts are performed correctly and correlate with the functionality of the account, performing an accounting expertise, followed by the fiscal functionality on the basis an accounting monography.

The Sales / Purchase Journal is not self-contained, but is part of a double debit / credit record that has a specific functionality and monography, and where things get complicated by reductions, discounts, awards, quantity bonuses, the accounting records and not the fiscal ones puzzle out the taxpayer's fiscal responsibility.

The tax expertise with reference to tax advisors cannot exist without the reports and records from the accounting records.

Law no. 149/2013, published in the Official Gazette no. 257 of 9th May, 2013, complements the normative acts regulating the activities of tax expertise, assessment of goods, financial audit, tax advisory and insolvency practitioner.

This law clearly stipulates that professionals in these fields can only perform complementary activities if they are qualified for it and are members of the organizations that coordinate the liberal professions concerned.

More specifically, Law no. 149/2013 provides that:

- The expert accountants can perform the financial audit, tax advisory and evaluation activities only after acquiring, under the law, the status of financial auditor, tax adviser or authorized evaluator, as the case may be, and after their enrolment as members in the organizations that coordinate the respective liberal professions.

- The tax advisors can perform the accounting expertise and financial audit activities only after acquiring, under the law, the status of an expert accountant or financial auditor, as case maybe, and after enrolling as members in the organizations that coordinate the respective liberal professions;

The above only determines the complete separation of all these complementary professions and expresses very clearly the conditions in which certain activities can be carried out. Accordingly, only this provision is reformulated and expressed more clearly, so that there should be no doubt that, for example, a tax advisor who wants to carry out accounting expertise activities must be expert accountant and CECCAR member.

\section{Case study}

In accordance with the database of judicial experts published by the Ministry of Justice, all judicial experts in accounting specialty had been selected in the first stage. According to the Order of the Ministry of Justice no. 199/2010, Annex 1 - Nomenclature of the specializations of the judicial technical expertise for accounting specialty, the experts can have one or more than one specialty out of those 9 specialties presented above.

A comparison between the total of judicial expert accountants and the expert accountants which have opted for accounting - taxability specialization had been performed. This analysis was presented under Figure no. 1. 
Figure 1. Judicial expert accountants, accounting specialty, reported to the total of judicial expert accountants

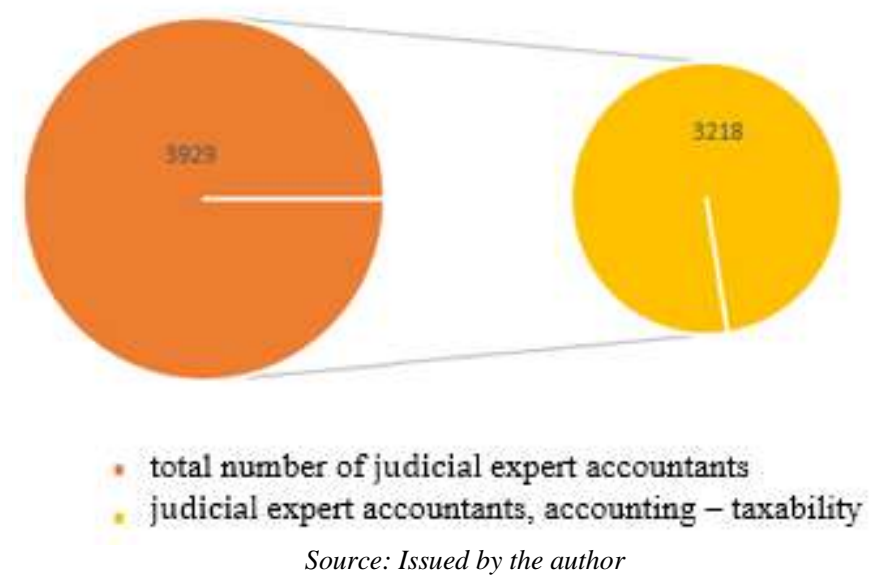
taxability

It can be observed that $82 \%$ of the judicial expert accountants are specialized in accounting -

But in case an accounting expertise has also objectives involving interpretation of the tax legislation, it cannot give an opinion.

At question no. 1 of the present study, namely: "Who performs an accounting - tax expertise?", there are two possible variants according to the legislation in force:

- Variant 1: It is divided in two types of expertise according to specialization, one accounting and the other fiscal.

- Variant 2: It is performed by a judicial expert, CECCAR and CCF member.

The first variant involves higher costs borne by the parties, and each expert answers only according to its objectives.

The second variant is more expensive for the technical expert, as he/she pays membership fees to two professional bodies, but it is beneficial for the quality and accuracy of the expertise. All samples are regarded as a whole by a professional who can express his/her opinion both from accounting and fiscal point of view on their accuracy and relevance.

In what concerns the answer to Question no. 2 and 3, it is centralized as follows:

- The expertise in taxability specialization is for determining some percentages and interpretation on the Codes' text, and not for the substance of the transactions, which is strictly accounting. As long as at the basis of any reporting lays an accounting record, any fiscal expertise is also accounting expertise, and the expert accountant appointed as judicial expert in criminal cases does not exercise any responsibility specific to the fiscal advisor capacity and does not perform any fiscal advisory activity. As long as the fiscal advisor reaches the basis of any reporting - an accounting record, he/she has exceeded his/her specialization, entering a domain where he/she has no competence.

- The expert accountant is found in the same situation, according to law, in the analysis of the fiscal aspects, although he/she uses them daily for performing accounting records. We do not doubt the knowledge of these professionals, no matter the body they come from, but we just want to underline the limitations they must submit to within the judicial expertise.

In the authors' opinion, for an accounting or fiscal expertise to be able to offer some pertinent, correct and complete conclusions, it is necessary to combine both fiscal and accounting competencies.

This opinion is shared by $62 \%$ of the tax advisors (Figure 2), which have also expert accounting capacity.

Figure 2 Judicial experts that belong to both professional bodies (CCF and CECCAR)

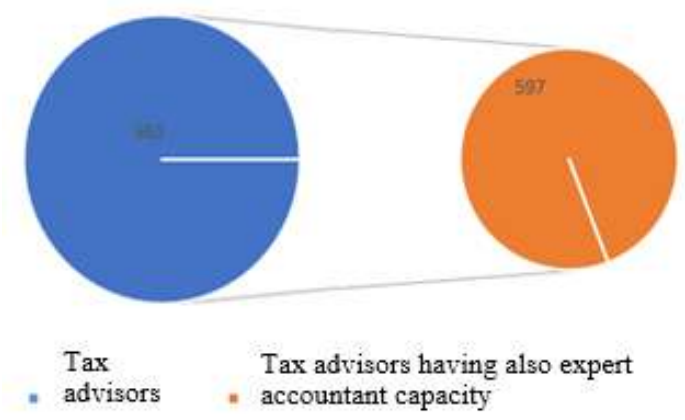

Source: Issued by the author 
The question is what happens to the other $38 \%$. There are also tax advisors who are financial auditors. However, there is another issue similar from legal point of view, according to which they cannot express their opinion even though they have the necessary knowledge in the accounting area as well.

The present case study is limited only to the comparative analysis of the two professions and focused on how to add value to the judicial accounting or fiscal expertise.

\section{Conclusions}

Judicial accounting is a science that supposes a synchronization in what concerns the relationship and application of financial, accounting, tax and audit knowledge in order to analyze, investigate, research, test and examine aspects of civil law, criminal law and jurisprudence.

The basic notions on accounting science are ignored, where factual accounting is the only source of information that generates the object of other activities, evaluation, audit, etc. If there is no basic information on the entity's patrimony, reflected by a fair and accurate accounting record, the other activities (audit, assessment, tax consultancy, insolvency) cannot be carried out.

Choosing an expert has always been a critical element in managing litigation cases. If a decision is made to appoint an independent expert, then it is essential to select the right person. A faulty appointment could have a significant impact on the outcome of the case. The process of selecting an expert requires a careful analysis on several criteria. First of all, it must be asked whether the expert to be appointed is, in fact, an expert on the requested subject.

The judicial expertise requires a wide range of skills in different situations. A judicial expert must have (investigative) detective and financial management skills. It must be able to identify unusual financial transactions. In the context of the legal dispute, the knowledge, skills and experience of a proper judicial expert are extremely useful as an advisor for litigation judges. The development of these skills requires a substantial amount of time, resources and money.

At the base of any reporting is an accounting record, so any tax expertise is also accounting expertise, and in the accounting records the tax issues are also pursued, so that any accounting expertise is also a fiscal expertise.

In conclusion, in compliance with the legal provisions and taking into account the above, in order for a judicial accounting and/or fiscal expertise to be complete and accurate, the judicial expert must be both an expert accountant and a tax advisor.

\section{References}

1. Borlea, N.S., Achim M.V., Breban, L. (2009), Financial Control and Accounting Expertise, Risoprint Publishing House, Cluj-Napoca;

2. Dobre E., Financial control, accounting expertise and audit - Ex Ponto Publishing House, Constanta, 2003;

3. Decision no. 3/2017 for the approval of the Regulation concerning the organization and operation of the Chamber of Tax Advisors, published in the Official Gazette no. 185/2017, available at the address: https://www .ccfiscali.ro/despre-ccf/legislatia-ccf/hotararilecamerei-si-ale-consiliului-superior/1340-hot-3-2017, accessed on the date of $12^{\text {th }}$ June 2019;

4. Ionescu, L. (2011), Accounting expertise in Romania. Theory and practice. $2^{\text {nd }}$ Edition. C.H. Beck Publishing House, Bucharest;

5. Law 198/2002 for the approval of the Government Ordinance no. 71/2001 on the organization and exercise of tax advisory activity;

6. Law no. 149/2013 on the approval of the Government Ordinance no. 23/2012 for the amendment and addition to the Government Emergency Ordinance no. 90/2008 on the statutory audit of the yearly financial statements and of the consolidated yearly financial statements and of the Government Ordinance no. 65/1994 on the organization of the accounting expertise and licenced accountants' activity and for changing other normative acts;

7. Law no. 200/2004 on the recognition of diplomas and professional qualifications for the professions regulated from Romania;

8. Order of the Ministry of Public Finances no. 306/2002 for the approval of simplified accounting regulations, harmonized with the European Directives;

9. Order of the Ministry of Public Finances no. 403/1999 for the approval of the accounting regulations harmonized with the $4^{\text {th }}$ Directive of the European Economic Communities and with the International Accounting Standards;

10. Order of the Ministry of Justice no. 199/2010 for the approval of the Nomenclature of the specializations of the judicial technical expertise;

11. Emergency Ordinance no. 75/1999 on financial audit activity;

12. Ordinance no. 65/1994 -on the organization of accounting expertise and licenced accountants activity, with subsequent changes;

13. Ordinance no.71/2001 - on the organization and exercise of fiscal advisory activity;

14. Regulation concerning the organization and operation of the Body of Expert and Licensed Accountants of Romania, available at the address: http://ceccar.ro/ro/?page_id=30, accessed on the date of 12 th June 2019;

15. Professional standard no. 35 on accounting expertise, $2^{\text {nd }}$ edition, reviewed and completed, CECCAR Publishing House, Bucharest, 2007; 